\title{
Studies on the Effects of Media on Growth and Nutritional Composition of Pleurotus Tuber-regium (Fries) Singer Mushroom
}

\author{
Onyeke, C.C., Onyishi, L. E., Okeke, O. S. and Nwachukwu, E. C. \\ Department of Botany, University of Nigeria, Nsukka
}

Corresponding author: Onyeke, C.C. Department of Botany, University of Nigeria, Nsukka

\begin{abstract}
The effects of different solutions and media on growth and nutrient composition of Pleurotus tuberregium were investigated. The different solutions used are glucose, fructose, sucrose and Knop's solutions. The media used are cassava agar, cocoyam agar, corn agar, potato agar and yam agar. Glucose solution produced the highest growth in stipe height $(9.50 \pm 0.91 \mathrm{~cm})$, stipe diameter $(4.46 \pm$ $0.59 \mathrm{~cm})$ and pileus diameter $(9.50 \pm 0.59 \mathrm{~cm})$. Knop's solution induced the least stipe diameter (7.20 \pm $0.59 \mathrm{~cm})$ while sucrose produced the least stipe diameter $(3.90 \pm 0.54 \mathrm{~cm})$ and pileus diameter $(7.50 \pm$ $0.95 \mathrm{~cm})$. Analyses of nutrient composition (\%) showed that fructose solution induced the highest protein $(13.6 \pm 0.99 \%)$ and fibre $(15.6 \pm 0.36 \%)$ contents. The highest oil $(15.0 \pm 0.17 \%)$ content was induced by glucose solution but it also induced the least protein $(3.06 \pm 0.09 \%)$ content. The best diametric mycelial extension (1.64cm \pm 0.087$)$, wet $(1.105 \pm 0.054 \mathrm{~g})$ and dry $(0.768 \pm 0.008 \mathrm{~g})$ weights were observed on cocoyam agar. The least diametric mycelial extensions of $1.26 \pm 0.087$ and $1.33 \pm 0.087 \mathrm{~cm}$ were produced on corn agar and potato agar, respectively. Corn agar gave the least wet $(0.845 \pm 0.084 \mathrm{~g})$ and dry $(0.74 \pm 0.008 \mathrm{~g})$ weights.
\end{abstract}

Keywords: Pleurotus tuber-regium, Growth, Nutritional composition, Sclerotium, Mushroom

Introduction

Pleurotus tuber-regium (Fries) Singer is an edible tropical mushroom which belongs to the phylum Basidiomycota, order Agaricales and family Agaricaceae (Zoberi, 1972; Alexopolous et al., 1996). It is naturally found growing on dead tree trunks where it produces sclerotia that can measure up to $30 \mathrm{~cm}$ and above in diameter (Oso, 1997). Both the selerotia and fruit bodies are delicacies in Nigeria (Fasidi and Ekuere, 1993). The sclerotium locally known as 'Osu' in Igbo land, southeastern Nigeria is useful in 'Egusi' soup thickening and other menus. The fruit bodies could be produced on a large scale from the sclerotia over a period of time depending on the size of sclerotium and the prevailing environmental conditions (Fasidi and Olorunmaiye, 1994).

$P$. tuber-regium is rich in protein, vitamins, minerals, crude fibre and ash, though their composition is dependent on the substrate type (Fasidi and Olorunmaiye, 1994; Stamets, 2000; Ogbo and Okhuoya, 2006) achieved a good mycelial growth of $P$. pulmonarius using Oat meal yeast agar and soybean husk as nutrient medium and agro-wastes, respectively.

Fasidi and Kadiri (1993) cultivated Lentinus subnudus using rice straw and dry wood and achieved fructification on logs of Spondias mombin and unfermented compost. Gbolagade et al. (2006) recorded the best mycelial extension (mm) of $L$. subnudus on potato dextrose agar (92.7) and malt extract agar (92.3). The work also reported that fructose and maltose best supported the growth of $L$. subnudus among other carbon compounds used. Mushroom cultivation in Nigeria is still at a very low scale despite its potential as a good substitute for animal protein which is not affordable to most Nigerians. Besides, mushrooms have antiallergic, anti-cholesterol, anti-tumour and anti- cancer qualities (Adejumo and Awosanya, 2005). Mushrooms are ideal for diabetic patients as they have low calorific values and high folic acid content. The present study investigated the effect of different solutions and media on growth and nutritional composition of $P$. tuber-regium.

\section{Materials and Methods}

Source of Sclerotia: The sclerotia used in this study were bought from Nsukka main Market, Enugu State, Nigeria.

Effect of Solutions on growth and nutritional composition of $\boldsymbol{P}$. tuber-regium: Sclerotia were cut to $98 \mathrm{~g}$ weights each. Each sclerotium was put in plastic container measuring $8 \mathrm{~cm}$ deep and $13 \mathrm{~cm}$ wide. The carbon sources used included glucose, fructose, sucrose and knop's solution. Solutions of all the carbon sources were prepared by dissolving $20 \mathrm{~g}$ of solutes inside beakers containing $500 \mathrm{ml}$ of de-ionized water. Knop's solution contained $0.8 \mathrm{~g}$ calcium nitrate, $0.2 \mathrm{~g}$ potassium nitrate, $0.2 \mathrm{~g}$ potassium hydrogen sulphate, $0.2 \mathrm{~g}$ magnesium sulphate, ferric sulphate (trace) and $1000 \mathrm{~cm}^{3}$ of deionized water.

The solutions were sprinkled on the sclerotia at the rate of $100 \mathrm{mls}$ each, daily for three days. On the fourth day the sclerotia in bowls were covered using nylon bags (to provide warmth). These bags were removed after three days as mushroom primordia appeared. Bowls were arranged in a completely randomised design (CRD) and replicated four times. The control experiments were similarly arranged but sprinkled accordingly with equal volume of de-ionised water. Measurements of stipe height, stipe diameter and pileus diameter were taken from different solutions 
after eight days of growth. The nutritional compositions of fruit bodies were determined in accordance with the procedures of AOAC (1985).

Effect of different media on mycelial growth of $P$. tuber-regium: The sclerotum of $P$. tuber-regium was tissue cultured on potato dextrose agar (PDA) in accordance with the method of Fasidi and Ekuere (1993). The food materials used in preparation of the growth media were cassava and yam tubers, cocoyam corms, yellow corn and Irish potato. These food materials were bought from Nsukka main market, Enugu State, Nigeria.

The method of preparation of media was similar to that of Gbolagade et al. (2006). Fifty grammes $(50 \mathrm{~g})$ of each of the food material was weighed out and emptied into $500 \mathrm{~cm}^{3}$ conical flasks each containing $250 \mathrm{~cm}^{3}$ of de-ionised water and brought to boil. The boiled food materials were ground and squeezed through cheese cloth over a funnel and the filtrates made up to $250 \mathrm{~cm}^{3}$ by adding more de-ionzed water. Ten grammes (10g) of agar-agar were dispensed into various filtrates and autoclaved at $121^{\circ} \mathrm{C}$ for 15 minutes. On cooling, 2-3 drops of streptomycin sulphate $(50 \mathrm{mg})$ were added to each of the media to suppress bacterial growth. The media were aseptically poured into $9 \mathrm{~cm}$ sterile Petri-dishes and allowed to solidify. Mycelial discs ( $3 \mathrm{~mm}$ in diameter) were obtained from 10-day old culture of $P$. tuber regium using a sterile cork-borer and placed up-side down at the centre of each of the solidified media. The plates were arranged in completely randomized design (CRD) replicated four times and incubated at room temperature $\left(27 \pm 1^{\circ} \mathrm{C}\right)$. Measurements of the mycelial diameters were taken eight days after inoculation by using a metre rule. Mycelial wet weights from the different media were determined by autoclaving the Petri-dishes at $121^{\circ} \mathrm{C}$ for 10 minutes as stated by Schisler and Volkoff (1977). The mycelial mat in each Petri-dish was carefully scrapped using camel brush and placed on No. 1 Whatman filter paper. The filter papers containing the mycelial mats were weighed on Microwave sensitive balance model 7720 . The mycelial wet weight was obtained by subtracting the weight of empty filter paper from that containing wet mycelial mat (Nwanze et al., 2005).

To determine the mycelial dry weights, filter papers containing mycelia were dried in an oven at $60^{\circ} \mathrm{C}$ till constant weights were obtained. The difference between the weights of dried filter papers containing mycelia and that of dried filter papers without mycelia was taken as the dry mycelial weight.

Statistical analyses: The standard errors (S.E) of data collected from the effects of carbon sources on growth and nutrient composition of $P$. tuber-regium were worked out. Data collected from the effects of different media on mycelial growth of $P$. tuberregium were subjected to square root transformation (where applicable) before using ANOVA and Duncan's multiple range tests to separate means.

\section{Results and Discussion}

Results on the effect of some carbon solutions on the growth and chemical composition of $P$. tuberregium are shown on Tables 1 and 2, respectively. The results show that solutions supported the growth of $P$. tuber-regium in varying degrees. Glucose solution produced the highest growth in stipe height $(9.50 \mathrm{~cm})$, stipe diameter $(4.40 \mathrm{~cm})$ and pileus diameter $(9.80 \mathrm{~cm})$. The least growth in stipe height, stipe diameter and pileus diameter was produced by Knop's solution $(7.20 \mathrm{~cm})$ and sucrose solution (3.90 and $7.50 \mathrm{~cm}$ ), respectively. The result on glucose solution is not surprising as it has been reported that glucose is easily utilized for growth by Pleurotus species (Alofe, 1985; Kadiri, 1990). Adejoye et al. (2007) also got similar results on Schizophyllum commune mushroom using sugar solutions as carbon sources.

Table 1: Effect of different solutions on the growth (cm) of $P$. tuber-regium

\begin{tabular}{lccc}
\hline Solutions & $\begin{array}{c}\text { Stipe } \\
\text { height }\end{array}$ & $\begin{array}{c}\text { Stipe } \\
\text { diameter }\end{array}$ & $\begin{array}{c}\text { Pileus } \\
\text { diameter }\end{array}$ \\
\hline Glucose & $9.50 \pm 0.91$ & $4.40 \pm 0.59$ & $9.80 \pm 2.24$ \\
Fructose & $8.20 \pm 1.45$ & $4.20 \pm 0.54$ & $7.70 \pm 2.24$ \\
Sucrose & $8.30 \pm 2.42$ & $3.90 \pm 0.54$ & $7.50 \pm 0.95$ \\
Knop's & & & \\
solution & $7.20 \pm 0.37$ & $4.00 \pm 0.55$ & $9.20 \pm 0.46$ \\
Control & $7.30 \pm 0.42$ & $3.80 \pm 0.31$ & $8.10 \pm 0.58$ \\
\hline
\end{tabular}

Results on the chemical composition of $P$.tuberregium fruit bodies showed that different carbon sources had different effects on the nutrient composition of mushroom. Fructose solution produced the highest protein (13.6\%) and fibre (15.6\%) contents in $P$. tuber-regium while the highest ash $(5.60 \%)$ and oil $(15.0 \%)$ were produced by sucrose and glucose solutions, respectively. The least protein content $(3.06 \%)$ was produced by glucose solution. Fasidi and Ekuere (1993) reported similar differences in nutrient composition of $P$. tuber-regium using cellulosic wastes as substrates. This result suggests that $P$. tuber-regium utilized the different sugars differentially in the syntheses of substances and cell components. The good percentage of protein found in the fruiting bodies of $P$. tuber-regium has indicated a good alternative to animal protein since meat is unaffordable to most Nigerians. It has also been reported that mushroom proteins are better than those of vegetables (Chan, 1981; Gbolagade et al., 2006). Results of the effects of media on mycelial extension of $P$. tuberegium are shown on Table 3 . The results show some significant differences $(P>0.05)$ in the growth of $P$. tuber-regium on some of the media. Cocoyam agar produced the best mycelial extension of $1.64 \mathrm{~cm}$, followed by yam agar $(1.59 \mathrm{~cm})$. The least mycelial extension of $1.26 \mathrm{~cm}$ was produced in corn agar. Cassava agar $(1.43 \mathrm{~cm})$ also supported good growth of $P$. tuber-regium. This result agrees with earlier reports that mushrooms are able to metabolize different carbon sources, though not with the same efficiency (Zoberi, 1973; Fasidi and Ekuere 1993; Jonathan and Fasidi, 2001; Gbolagade et al., 2006). 
Table 2: Proximate Composition (\%) of P. tuber-regium fruit bodies grown on different solutions

\begin{tabular}{lcccc}
\hline Solutions & Protein & Fibre & Ash & Oil \\
\hline Fructose & $13.6 \pm 0.99$ & $15.6 \pm 0.36$ & $5.00 \pm 0.18$ & $10.0 \pm 0.18$ \\
Glucose & $3.06 \pm 0.09$ & $15.0 \pm 0.60$ & $5.00 \pm 0.39$ & $15.0 \pm 0.17$ \\
Sucrose & $4.11 \pm 0.26$ & $15.0 \pm 0.11$ & $5.50 \pm 0.29$ & $10.0 \pm 0.21$ \\
Knop's Solution & $4.20 \pm 0.61$ & $15.0 \pm 0.21$ & $5.00 \pm 1.01$ & $10.0 \pm 0.16$ \\
Control & $4.30 \pm 0.63$ & $11.5 \pm 0.81$ & $4.00 \pm 0.22$ & $13.0 \pm 0.16$ \\
\hline
\end{tabular}

Table 3: Effects of Media on mycelial growth of $P$. tuber-regium

\begin{tabular}{lc}
\hline Media & Growth(cm) \\
\hline Cassava agar & $1.43 \pm 0.087 \mathrm{abc}$ \\
Cocoyam agar & $1.64 \pm 0.078 \mathrm{a}$ \\
Corn agar & $1.26 \pm 0.067 \mathrm{c}$ \\
Potato agar & $1.33 \pm 0.070 \mathrm{bc}$ \\
Yam agar & $1.59 \pm 0.030 \mathrm{ab}$ \\
\hline
\end{tabular}

Table 4 shows results on the effects of media on the mycelial weight (Wet and dry) of $P$. tuberregium. This showed significant differences $(P>$ 0.05 ) in weights (wet and dry) for the different media. Cocoyam agar produced the highest wet $(1.105 \mathrm{~g})$ and dry $(0.768 \mathrm{~g})$ weights.

Table 4: Effects of Media on the mycelial wet and dry weights of $P$. tuber-regium

\begin{tabular}{lcc}
\hline Media & Wet weight(g) & Dry weight (g) \\
\hline Cassava agar & $1.089 \pm 0.044 \mathrm{a}$ & $0.752 \pm 0.008 \mathrm{ab}$ \\
Corn agar & $0.845 \pm 0.054 \mathrm{c}$ & $0.739 \pm 0.008 \mathrm{~b}$ \\
Potato agar & $1.040 \pm 0.062 \mathrm{ab}$ & $0.749 \pm 0.004 \mathrm{ab}$ \\
Yam agar & $0.906 \pm 0.034 \mathrm{bc}$ & $0.743 \pm 0.008 \mathrm{~b}$ \\
\hline
\end{tabular}

This was followed very closely by cassava agar, which recorded $1.089 \mathrm{~g}$ and $0.752 \mathrm{~g}$ for wet and dry weights, respectively. The least wet $(0.845 \mathrm{~g})$ and dry $(0.739 \mathrm{~g})$ weights were produced by corn agar. Cocoyam agar maintained its lead on the best mycelial extension both in wet and dry weights. This indicates that $P$ tuber-regium prefers cocoyam agar to other media investigated. This result is similar to that of past workers who demonstrated the utilizability of synthetic media by mushrooms (Gbolagade et al., 2006; Okwulehie et al., 2006). Yam agar was very good in mycelial extension but did poorly in both wet and dry weights production. On the basis of weight, cocoyam agar is better than yam agar for the growth of $P$. tuber-regium.

\section{References}

Adejoye, O. D. Adebayo, B. C, Ogujobi, A. A. and Afolabi, O. O. (2007). Physiological studies on Schizohyllum commune (Fries) a Nigerian edible mushroom. World Applied Sciences, 2 (1): 73 - 76.

Adejumo, T. O. and Awosanya, O. B. (2005). Proximate and mineral composition of four edible mushroom species from South Western Nigeria. African Journal of Biotechnology, 4(10): $1084-1088$

Alexopoulos, C. J., O. Mim, C. W. and Blackwell, M. (1996). Introductory Mycology. (4 ${ }^{\text {th }}$ Ed.). John Wiley, New York. 869 pp.

Alofe, F. V. (1985). The general characteristics and cultivation of some Nigerian Mushrooms.
PhD Thesis, Obafemi Awolowo University, Ile-Ife, Nigeria.

AOAC (1987). The Official Methods of Analysis. Washington, D.C. 219 pp.

Chan, H. K. M. (1981). Consumption of edible mushrooms in Hong Kong. Mushroom Newsletter Tropics, 1(4): 5-10.

Fasidi, I. O. and Ekuere, U. U. (1993). Studies on Pleurotus tuber-regium (Fries) Singer: cultivation, proximate composition and mineral contents of sclerotia. Food Chemistry, 48: 255 - 258.

Fasidi, I. O. and Kadiri, M. (1993). Effect of sporophore maturity on chemical composition of Volvariella esculenta (Mass) Singer, a Nigerian edible mushroom. Die Nahrung, 37(3): $269-273$.

Fasidi, I. O. and Olorunmaiye, K. S. (1994). Studies on the requirements for vegetative growth of Pleurotus tuber -regium (Fries) Singer a Nigerian mushroom. Food Chemistry, 50: $397-401$.

Gbolagade, J. S., Fasidi, I. O., Ajayi, E. J. and Sobowale, A. A. (2006). Effect of physicochemical factors and semi-synthetic media on vegetative growth of Lentinus subnudus (Berk.), an edible mushroom from Nigeria. Food Chemistry, 99: 742 - 747.

Jonathan, S. G. and Fasidi, I. O. (2001). Effect of carbon, nitrogen and mineral sources in growth of Psythyrella atroumbonata (Pegler), a Nigerian edible mushroom. Food Chemistry, 50: 397 - 401.

Kadiri, M. (1990). Physiological studies on some Nigerian mushrooms. PhD Thesis, University of Ibadan, Ibadan, Nigeria.

Nwanze, P. I., Khan, A. U., Ameh, J. B. and Umoh, V. J. (2005). The Effect of media, oil type and rate on the mycelial wet and dry weights of Lentinus squarrulosus (Mont.) Singer and Psathyrella atroumbonata Pegler in submerged liquid culture. African Journal of Biotechnology, 4(3): 326 - 331.

Ogbo, M. E. and Okhuoya, J. A. (2006). The Effects of different substrates on sporophore yield and nutrient content of $P$. tuber-regium (Fries) Singer. Nigerian Journal of Botany, 19(2): 200-205.

Okwulehie, I. C., Okwujiako, I. A. and Igbojionu, V. C. (2006). Studies on nutritional requirements and growth of Pleurotus pulmonarius (Fries) Quelet, an exotic mushroom. Nigerian Journal of Botany, 19(2): 308-316.

Oso, B. A. (1997). Pleurotus tuber-regium from Nigeria. Mycologia, 67: 311-319.

Schisler, L. C. and Volkoff, O. (1977). The Effect of Safflower oil on mycelial growth of 
Boletaceae in submerged liquid cultures. Mycologia, 69:118 - 125.

Stamets, P. (2000).Growing gourmet and medicinal mushrooms. Tenspeed Press, Toronto. 574pp.
Zoberi, M. H. (1972). Tropical Macro fungi. London, Macmillan.

Zoberi, M. H. (1973). Some edible mushrooms from Nigeria. Nigerian Field, 38: 81 - 90. 